\title{
EDITORIAL
}

\section{Tradução e recepção: literaturas traduzidas}

\section{II}

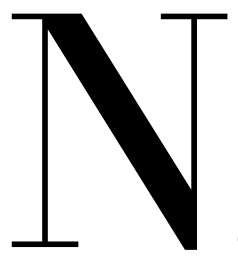

este volume, o segundo ${ }^{1}$ dedicado, em 2017, aos estudos do grupo de pesquisa Literatura Traduzida, reunimos alguns trabalhos pertencentes a outro côté da pesquisa, recentemente ampliada para acolher dados e reflexões sobre a recepção da literatura brasileira na Itália e sobre recepção e traduções da literatura italiana em outros países, graças a contribuições de pesquisadores italianos e outros. A extensão das pesquisas às relações entre literatura e cultura italiana e brasileira, via tradução, agora dos dois lados do oceano, é um passo importante rumo a novos mapeamentos, preciosos para a divulgação, inclusive, da literatura brasileira na Itália.

Do ponto de vista da recepção da literatura brasileira na Itália, Erica Salatini pensa no

1 Para maiores esclarecimentos sobre os critérios norteadores das pesquisas do grupo, reenviamos o leitor ao Editorial do número anterior da Revista, o XXXIII. 
encontro de Antonio Tabucchi com a obra poética de Carlos Drummond de Andrade; as relações cultura, ideologia e tradução são tema do artigo de Maria Gloria Vinci: o contexto de chegada é a cultura italiana dos anos cinquenta, dominada pela contraposição entre partido comunista e Democrazia Cristiana. A tradução do romance de Jorge Amado, Capitães da areia, é definida por Gloria quase uma "adaptação" - com finalidades ideológicas e "educativas" - pelos cortes, omissões, e reescrituras de partes do original. No fim dessa seção, apresentamos o artigo de Amina Di Munno, brasilianista da Universidade de Gênova e tradutora de literatura brasileira para o italiano, que participou conosco, com palestras e oficinas de tradução, da III Jornada Paulista da Literatura Italiana Traduzida (São Paulo, novembro de 2015), que estuda o tema da cidade na narrativa brasileira contemporânea.

Quanto à literatura italiana traduzida no Brasil, Adriana Iozzi e Lucia Wataghin traçam um quadro atualizado da literatura italiana traduzida no Brasil; Aline Fogaça trata das antologias, um formato específico em que se pode dar a recepção de autores e obras em tradução, e em especial da forte presença de Giovanni Papini em antologias de contos publicadas no Brasil nos anos sessenta. Ana Paula Andrade, por sua vez, trata da ideia de um futurismo "compósito", veiculado nas crônicas publicadas no Correio Paulistano por Menotti del Picchia, em tempos (anos vinte) em que os modernistas "devoraram" conceitos e práticas do futurismo italiano, ajustados à realidade brasileira e Gesualdo Maffia tece comentários sobre as traduções brasileiras de Lettere dal carcere de Antonio Gramsci. Temos, enfim, um relato detalhado das traduções de Pirandello no Brasil, objeto da tese do doutorado em co-tutela USP/Università di Roma Tor Vergata, defendido por Sandra Dugo na Universidade de Roma Tor Vergata em 2015.

Uma seção separada foi dedicada aos artigos de Silvia Cattoni e Fernando Ibarra, nossos convidados a participar da IV Jornada Paulista da Literatura Italiana Traduzida, realizada na Universidade de São Paulo em março de 2016. Os artigos tratam, respectivamente, da literatura italiana traduzida na Argentina e no México.

No final deste número da revista, publicamos a versão atualizada com os resultados das pesquisas do último biênio do Projeto de Pesquisa Regular, apresentado à Fapesp, em 2014, com o título "Mapeamento e dicionário da Literatura Italiana Traduzida". ${ }^{2}$

Agradecemos à Fapesp pelo apoio concedido, que permitiu dar continuidade ao dicionário

2 Projeto de pesquisa regular FAPESP sob o número 2013/20971-0. 
virtual, criado na UFSC em $2010^{3}$, e de realizar viagens e encontros dos pesquisadores ligados ao projeto. Agradecemos, por fim, à Revista de Italianística, por hospedar os nossos trabalhos.

Andrea Santurbano, Lucia Wataghin, Patricia Peterle

3 Em 2010 o projeto obteve financiamento da UFSC, com o edital FUNPESQUISA, e em 2011 teve o apoio do CNPq, no edital Ciências Humanas n. 400500/2010-8. 